\title{
Production of Jaadi using Tilapia (Oreochromis niloticus) and determination of its physcio-chemical and sensory properties
}

\author{
Lakshmi W.G.I ${ }^{1}$, Prassanna P.H.P ${ }^{1}$ and Edirisinghe U. $^{2}$
}

${ }^{I}$ Department of Agricultural Systems, Faculty of Agriculture, Rajarata University of Sri Lanka, Puliyankulama, Anuradhapura, Sri Lanka.

${ }^{2}$ Departments of Animal Science, Faculty of Agriculture, University of Peradeniya, Peradeniya, Sri Lanka.

\begin{abstract}
Consumption of Tilapia is restricted due to its muddy flavour and colour. This study was aimed to develop jaadi, a fermented fish product, using Tilapia (Oreochromis niloticus) and to determine suitable salt and goraka (Garcinia gambodiea) combination for its preparation. The experiment was arranged in a Randomized Complete Block Design with four replicates. First experiment was aimed at determining the suitable salt content for jaadi. There were four treatments having salt contents of $200 \mathrm{~g}, 300 \mathrm{~g}, 400 \mathrm{~g}$ and $500 \mathrm{~g}$ per $1 \mathrm{~kg}$ of deskined fish without head while keeping goraka (G. gambodiea) content at $100 \mathrm{~g}$. The most suitable salt content was determined according to sensory evaluation results, which in turn was used for second experiment, for the determination of suitable goraka (G. gambodiea) content, the goraka (G. gambodiea) content was changed as $100 \mathrm{~g}, 150 \mathrm{~g}, 200 \mathrm{~g}$ and $250 \mathrm{~g}$ per $1 \mathrm{~kg}$ of fish keeping the salt content constant. Results for the first experiment indicated that the highest preference for sensory attributes was from combination of $500 \mathrm{~g}$ of salt with constant goraka (G. gambodiea) per $1 \mathrm{~kg}$ of fish. Results of second experiment indicated that there was a higher preference for the combination of $100 \mathrm{~g}$ of garcenia (G. gambodiea) with $500 \mathrm{~g}$ salt per $1 \mathrm{~kg}$ of fish compared to other treatments. The study clearly revealed that $500 \mathrm{~g}$ of goraka (G. gambodiea) and 100 $\mathrm{g}$ of salt with $1 \mathrm{~kg}$ of deskined Tilapia (O. niloticus) fish without head can effectively used to produce jaadi.
\end{abstract}

Key words: Tilapia, Goraka, Salt, Storage

\section{Introduction}

Fish is considered as an important food item in the diet of South East Asian people particularly as a source of protein. Over $96 \%$ of Sri Lankans consume fresh or processed fish, which provide an estimated $65-70 \%$ of the mean annual protein intake (Gunerathne and Samarajeewa, 1994). More than $95 \%$ of the fish production in Sri Lanka is from capture fisheries; the rest is from aquaculture (FAO, 1996). The introduction of exotic fish tilapia species has increased the fish yields from $1 \mathrm{~kg} /$ ha to $227 \mathrm{~kg} / \mathrm{ha}$ per year and has contributed towards establishment of capture based culture fisheries (De Silva, 1981). 
As Tilapia is produced in seasonal tanks, over production result during in the peak season and leads to post harvest losses. Hence, proper application of post harvest technology is needed to overcome this problem. Direct consumption of Tilapia is restricted due to lack of taste leading for a less popularity of Tilapia among consumers except in Dry Zones. Therefore, value added product with good physico-chemical properties could be used to attract and encourage people to consume Tilapia as a good protein source. The jaadi is wet cured traditional fermented fishery product and creates a pleasant, mouth watering sensation in our tongues (Weerasinghe, 1991). Jaddi is a Tamil word and its means huge pots. Indian people also call 'Thaadi'. In pali it is known as 'Thathi' (kariyawasam, 2007). Therefore, this study was undertaken develop a fermented fish product, jaadi, using Tilapia (O. niloticus), to evaluate sensory properties of the product and changes in $\mathrm{pH}$ value of product during storage.

\section{Materials and Methodology}

\section{Preliminary processing of fish}

This study was carried out at Aquaculture laboratory, Department of Animal Science, Faculty of Agriculture, University of Peradeniya, Preradeniya, Sri Lanka. Approximately, 300-350g of weight and $25 \mathrm{~cm}$ (from snout to base of the caudal fin) of total length fish were selected for processing. Preprocessing inspection of fish was done to select fish without any defects like cuts, bruises, cruises or discolouration. The belly area was cut opened and the internal organs like digestive track, uro-gentital systems were removed. Body cavity was cleaned using clean water. All the fins were removed except the caudal fin. Deheading of fish were done by cutting the head as canting the head as a contoured cut which run perpendicular to the fish's backbone and then at an angle of $45^{\circ}$ manually. Pectoral bones were also removed along the head. Skinning was done to reduce microbial count and to remove scales. Finally caudal fin was removed and carcasses were washed using clean water. During processing period, contamination by flies was never allowed. $0.3 \mathrm{~m}$ diameter and $0.25 \mathrm{~m}$ height clay pots were taken and washed thoroughly by using tap water and sterilized by boiling water. Goraka (G. gambodiea) was also washed and sterilized with boiling water before using.

\section{Preparation of jaadi}

The experiment was arranged in a Randomized Complete Block Design with four replicates. Salt and goraka (G. gambodiea) were mixed well, produce as curing mixture and packed in previously washed and sterilized 
clay pots in alternative layers of fish and prepared curing mixture. It would be noted that salt and goraka (G. gambodiea) mixture was thickly sprinkled between each layers and also the top most layer s of fish and the bottom of the container was covered with salt and goraka (G. gambodiea) mixture. Clay pots were covered by using cleaned banana leaves and tied up with threads to avoid any possible contaminations and set a side for natural fermentation to proceed uninterrupted for a period of three months.

\section{Determination of suitable salt quantities for preparation of jaadi}

Four jaadi samples were prepared based on recipe given in Table 1. Sensory evaluation (colour, flavour, odour and over all acceptance) was carried out at the end of the experiment to find out the optimum salt content to produce good quality jaadi.

Table 1: Combination of Goraka and Salt Content for $1 \mathrm{~kg}$ of Fish

\begin{tabular}{|l|l|l|}
\hline Treatments & $\begin{array}{l}\text { Goraka cont ent } \\
\text { (g/kg of fish) }\end{array}$ & $\begin{array}{l}\text { Salt content } \\
\text { (g/kg of fish) }\end{array}$ \\
\hline $\mathbf{T}_{\mathbf{1}}$ & 100 & 200 \\
\hline $\mathbf{T}_{\mathbf{2}}$ & 100 & 300 \\
\hline $\mathbf{T}_{\mathbf{3}}$ & 100 & 400 \\
\hline $\mathbf{T}_{\mathbf{4}}$ & 100 & 500 \\
\hline
\end{tabular}

\section{Determination of the suitable goraka (G. gambodiea) quantities for preparation of jaadi}

Based on the results of sensory evaluation for determining the optimum quantity salt for the preparation of jaadi, optimum quantity of goraka $(G$. gambodiea) was determined using treatments as shown in Table 2. At the end of three months period a sensory evaluation was carried out to determine the optimum quantity of goraka (G. gambodiea).

Table 2: Combination Goraka Content for 1 kg of Fish

\begin{tabular}{|l|l|}
\hline Treatments & Goraka content $(\mathrm{g} / \mathrm{kg}$ of fish) \\
\hline $\mathbf{T}_{\mathbf{1}}$ & 100 \\
\hline $\mathbf{T}_{\mathbf{2}}$ & 150 \\
\hline $\mathbf{T}_{\mathbf{3}}$ & 200 \\
\hline $\mathbf{T}_{\mathbf{4}}$ & 250 \\
\hline
\end{tabular}




\section{Determination of $\mathrm{pH}$ of the final products during storage}

The final product was prepared using the optimum salt and goraka $(G$. gambodiea) contents found in the study. The product was storage for period of four months at ambient temperature $27^{\circ} \mathrm{C}$ and $\mathrm{pH}$ value of the product was determined using a digital Hanna $\mathrm{pH}$ meter at one month interval to find out mould with storage.

\section{Sensory Evaluation}

Acceptability of the product was tasted by preparing a curry of jaadi samples and randomly coded and served to a panel of 30 in-house untrained 25 years male and female panellists from Faculty of Agriculture, University of Peradeniya, Peradeniya, Sri Lanka. They assessed colour, odour, flavour and overall acceptability of each sample supplied. Each parameter was ranked on a 5-point Hedonic scale (5- Like very much 1- Dislike very much).

\section{Statistical Analysis}

The results of sensory evaluation were analyzed by Friedman test using MINITAB statical package á $=0.05$ and means were separated by multiple comparison. Data related to the $\mathrm{pH}$ changes were separated according to the Duncan's Multiple Ranges Test (DMRT).

\section{Results and discussion}

\section{Determination of suitable salt content}

Result revealed that there was a significant deference $(\mathrm{P}<0.05)$ for taste and overall acceptable of treatment $\mathrm{T}_{4}$ having $500 \mathrm{~g}$ goraka (G. gambodiea) (Table 3). $\mathrm{T}_{1}$ containing $200 \mathrm{~g}$ salt and $100 \mathrm{~g}$ goraka (G. gambodiea) was the least preferred one. Therefore, $500 \mathrm{~g}$ salt level was selected as the optimum salt level and used for the next experiment to determine optimum goraka (G. gambodiea) content. Weerasinghe (1991) reported a different finding for preparation of jaadi from marine fish that $100 \mathrm{~g}$ of salt could be used for $300 \mathrm{~g}$ of fish. Salt to fish ratio for Tilapia Jaadi was 1:2 while Weerasinghe (1991) used 1:3 salt to fish in his study to have a good quality jaadi. 
Table 3: The median values for determination of suitable salt content

\begin{tabular}{|l|l|l|l|l|l|}
\hline \multirow{2}{*}{ Treatments } & \multicolumn{5}{|c|}{ Median Values } \\
\cline { 2 - 6 } & Colour & Taste & Odour & Texture & $\begin{array}{l}\text { Overall } \\
\text { acceptability }\end{array}$ \\
\hline $\mathbf{T}_{1}$ & $2.70^{\mathrm{a}}$ & $3.0^{\mathrm{a}}$ & $3.2^{\mathrm{a}}$ & $2.93^{\mathrm{a}}$ & $3.0^{\mathrm{a}}$ \\
\hline $\mathbf{T}_{2}$ & $2.20^{\mathrm{a}}$ & $3.0^{\mathrm{a}}$ & $3.0^{\mathrm{a}}$ & $2.56^{\mathrm{a}}$ & $3.0^{\mathrm{a}}$ \\
\hline $\mathbf{T}_{3}$ & $3.30^{\mathrm{b}}$ & $4.0^{\mathrm{ab}}$ & $3.3^{\mathrm{a}}$ & $3.00^{\mathrm{a}}$ & $3.0^{\mathrm{a}}$ \\
\hline $\mathbf{T}_{4}$ & $3.59^{\mathrm{b}}$ & $4.0^{\mathrm{b}}$ & $3.5^{\mathrm{a}}$ & $3.10^{\mathrm{a}}$ & $4.0^{\mathrm{b}}$ \\
\hline
\end{tabular}

Note: Median Values in columns with the same letter are not significantly different (á = $0.05)$.

\section{Determination of suitable goraka ( $G$ gambodiea) content}

Results indicated that there was no difference $(\mathrm{p}>0.05)$ for colour, odour and texture of treatments (Table 4). Taste and overall acceptability of treatment $\mathrm{T}_{5}$ having $100 \mathrm{~g}$ goraka (G. gambodiea) and $500 \mathrm{~g}$ salt were significant from other treatments at á $=0.05$. Therefore, $100 \mathrm{~g}$ goraka $(G$. gambodiea) was selected as the optimum goraka ( $G$. gambodiea) content resulting premium quality jaadi. The final jaadi samples were prepared with $500 \mathrm{~g}$ salt, $100 \mathrm{~g}$ goraka (G. gambodiea) and $1 \mathrm{~kg}$ of deskined Tilapia without their heads. A similar result for jaadi was reported by Weeerasinghe (1991). Furthermore indicated that $100 \mathrm{~g}$ goraka (G. gambodiea) could be effectively used with $1 \mathrm{~kg}$ of marine fish to have very good quality jaadi. Result further revealed that goraka (G. gambodiea): fish ratio for both studies was $1: 10$.

Table 4: The Median Values for Determination of Suitable Goraka Content

\begin{tabular}{|l|l|l|l|l|l|}
\hline \multirow{2}{*}{ Treatments } & \multicolumn{5}{|c|}{ Median Values } \\
\cline { 2 - 6 } & Taste & Colour & Odour & Texture & $\begin{array}{l}\text { Overall } \\
\text { acceptability }\end{array}$ \\
\hline $\mathbf{T}_{\mathbf{1}}$ & $4.0^{\mathrm{a}}$ & $3.75^{\mathrm{a}}$ & $3.75^{\mathrm{a}}$ & $3.62^{\mathrm{a}}$ & $3.75^{\mathrm{a}}$ \\
\hline $\mathbf{T}_{2}$ & $3.0^{\mathrm{b}}$ & $3.25^{\mathrm{a}}$ & $3.25^{\mathrm{a}}$ & $3.37^{\mathrm{a}}$ & $3.50^{\mathrm{a}}$ \\
\hline $\mathbf{T}_{3}$ & $3.0^{\mathrm{b}}$ & $3.50^{\mathrm{a}}$ & $3.50^{\mathrm{a}}$ & $3.37^{\mathrm{a}}$ & $3.50^{\mathrm{a}}$ \\
\hline $\mathbf{T}_{4}$ & $2.0^{\mathrm{b}}$ & $3.50^{\mathrm{a}}$ & $3.50^{\mathrm{a}}$ & $3.12^{\mathrm{a}}$ & $3.25^{\mathrm{a}}$ \\
\hline
\end{tabular}

Note: Sums of Ranks in columns with the same letter are not significantly different (á $=$ $0.05)$. 


\section{Changes in $\mathrm{pH}$ values of jaadi samples stored at ambient temperature $27^{\circ} \mathrm{C}$}

$\mathrm{pH}$ level of jaadi samples did not changed significantly (P>0.05) for a period of 4 months (Table 5). It proves that there are quality changes in prepared jaadi during storage especially growth of harmful microorganisms like mould. Goraka (G. gambodiea) was used as a souring agent for this experiment because it contains gambogic acid, which helps in preservative action by reducing $\mathrm{pH}$ (Amarasinghe and Jayaweera, 1994). Further it acts as an antimicrobial agent retarding the microbial growth due to forming acidic medium. Pathmalatha (2001) indicated that $\mathrm{pH}$ of goraka (G. gambodiea) is around 4 and it can inhibit undesirable microbial growth. Weersinghe (1991) indicated different results for $\mathrm{pH}$ in marine jaadi that was around 4.2. This difference may be due to higher salt content used in this study. The remarkable feature of this study was that there was no any mould growth or bad smell in jaadi even after 4 months of storage.

Table 5: The $\mathrm{pH}$ Values during Storage

\begin{tabular}{|l|l|}
\hline Months & $\mathbf{p H}$ Value \\
\hline 1 & $5.08^{\mathrm{a}}$ \\
\hline 2 & $5.06^{\mathrm{a}}$ \\
\hline 3 & $5.09^{\mathrm{a}}$ \\
\hline 4 & $5.07^{\mathrm{a}}$ \\
\hline
\end{tabular}

Note: Sums of Ranks in columns with the same letter are not significantly different (á = $0.05)$.

\section{Conclusions}

The Premium quality jaadi could be prepared by using $1 \mathrm{~kg}$ of deskined Tilapia (O. niloticus) without head, $500 \mathrm{~g}$ salt and $100 \mathrm{~g}$ goraka $(G$. gambodiea). There was no change in $\mathrm{pH}$ level of stored jaadi samples for 4 months period at ambient temperature $27^{\circ} \mathrm{C}$.

\section{References}

Amarasighe, B.D.V. and Jayaweera, V. (1994) Extension of the shelf life of Ambul Thiyal. Journal of National Aquatic Resources and Development Agency, v. 32, pp. 2-8. 
De Silva, S.S. (1981) Reservoir fishery present status and future target, Journal of Inland Fisheries, v. 2, pp. 23-32.

Food and Agriculture Organization (FAO), (1996) Country Profile Sri Lanka, Rome Food and Agriculture Organization of the United Nations, pp. 30.

Gunarathne, S. and Samarajeewa, U. (1994) A Study on histamine production and control measures for fish and dried fish and the effect of processing on histamine, M.Sc. Thesis, Department of Food Science, Faculty of Agriculture, University of Peradeniya, pp. 38-39.

Karyawasam, S. (2007) "Karige theeruwa", Lankadeepa Newspaper, Colombo, Vijaya Publications, pp.7.

Pathmalatha, A.G.L.A. (2001) "Preparation of Jaadi" B.Sc. Mini Project, Department of Animal Sciences, Faculty of Agriculture, University of Peradeniya, pp. 1-2.

Weerasinghe, T.J. (1991) "Jaadi" Journal of NARA, Corw Island, Mattakkuliya, Colombo15, pp. 3-8. 